But the three-hundredth anniversary of his birth is happily marked by the publication by Prof. Clifford Dobell of a handsome volume entitled "Antony van Leeuwenhoek and his 'Little Animals' being some Account of the Father of Protozoology and Bacteriology and his Multifarious Discoveries in these Disciplines". Prof. Dobell has been called Leeuwenhoek's "greatest living admirer" and his book is worthy of his hero. How he was led to the study of Leeuwenhoek's letters in the original Dutch, what difficulties he met with and how these were gradually overcome are set forth in an entertaining prefatory epistle, while after this come chapters dealing with the life of Leeuwenhoek, his observa. tions on protozoa and bacteria, his microscopes and methods of work, his language, his writings and other matters. Leeuwenhoek appears to have been singularly free from prejudice and in one of his letters wrote: "As I aim at nothing but Truth, and so far as in me lieth, to point out Mistakes that may have crept into certain Matters; I hope that in so doing those I chance to censure will not take it ill; and if they would expose any Errors in my own Discoveries, I'd esteem it a Service; all the more, because 'twould thereby give me Encouragement towards Attaining of a nicer Accuracy."

\section{Australian National Research Council}

As the annual meeting of the Australian National Research Council held in Sydney in August, it was determined to make a special effort to secure further financial support for the chair of anthropology which was established in the University of Sydney some time ago through the activity of the Council. The existence of the chair is threatened by recent reductions in government grants. In recognition of the work of its first two presidents, Sir. T. W. Edgeworth David and Sir David Orme Masson, the Council has established two lectureships to be awarded alternately at two year intervals, the David lectureship, commenoing in 1933, to be devoted to geology or biology, the Masson lectureship, commencing in 1935, to physics or chemistry. A bronze medal in honour of Sir Thomas Ranken Lyle, the retiring president, is to be struck and it will be awarded not more frequently than every second year to such Australian worker in mathematics and physics as may appear to the Council to be worthy of the honour. The incoming officers are: President, Sir George A. Julius; Vice-Presidents, Sir William Mitchell, Dr. A. C. D. Rivett, Prof. N. T. M. Wilsmore, Prof. H. C. Richards; Secretary, Mr. A. J. Gibson; Treasurer, Dr. H. G. Chapman; Executive Committee, Sir Douglas Mawson, Profs. Agar, Watt, Osborn and Goddard, Drs. Waterhouse and Dickson, and Messrs. Andrews, Gepp and Wainwright.

A LONG discussion as to the future policy of the Australian National Research Council and its relationship to the International Research Council took place at the annual meeting. The standing of the Council as a national academy of sciences for the Commonwealth was reaffirmed and, with the object of stimulating its working in certain respects, the executive committee was requested to introduce such changes in constitution and by-laws as might be necessary to give effect to the following objects :(1) the institution of a very limited fellowship; (2) the appointment of distinguished overseas scientific workers who have been associated with science in Australia as honorary overseas fellows; (3) migration of headquarters between capital cities ; (4) alteration in rules of appointment to the executive committee to ensure more frequent changes in personnel and to effect closer contact with Royal Societies and other scientific bodies; (5) the display of greater initiative and leadership in the attack upon major problems associated with science in Australia, the Mandated Territories and the Australian quadrant of the antarctic continent; (6) the devising of practical means for bringing members in all centres into more intimate touch with the handling of these problems; and (7) the formation of a committee to explore the possibilities of a federation of Royal Societies and certain other scientific organisations in Australia.

\section{Exhibition of Inventions}

THE eighth International Exhibition of Inventions organised by the Institute of Patentees (Incorporated) was opened at the Central Hall, West. minster, on October 5 by Sir Maurice Jenks, the Lord Mayor of London. The opening was followed by a luncheon at St. Ermin's Restaurant, when Lord Askwith, president of the Institute, remarked that it is not the old men, but the young, who are bringing marvellous things into the world. As in former years, the exhibition is divided into two main sections, a trade section which includes many things already on the market, and a section of new inven. tions, the latter being sub-divided into groups of exhibits relating to domestic and labour-saving appliances, electrical and radio apparatus, building and housing details and mechanical apparatus. As might be expected, the last of these groups contains many new devices for motor vehicles such as brakes, lights, signalling signs and means for preventing cars being stolen. One interesting exhibit is a small electrically driven model boat in a tank for demonstrating the increase in efficiency of the propeller obtained by surrounding it with a ring of approxi. mately cone section. Other exhibits relate to internal combustion engines and to variable speed gear and transmission gear.

\section{A Reversing Centrifugal Gear}

Among the last group of exhibits in the Inventions Exhibition is the new epicyclic gearing invented by Prof. F. Soddy, the main object of which is to provide for the transmission of large powers at high speed, and for reversing without declutching. The gear in one form or another is therefore suitable for use with steam turbines or high-speed marine engines. Unlike most epicyclic gears, there are in it no toothed wheels. The driving and driven shafts are co-axial. On the end of the driving shaft are

$$
\text { No. 3285, VoL. 130] }
$$


two cranks at $180^{\circ}$ apart and these drive two heavy 'planets', which have a slight freedom of movement in a radial direction relative to the crank pins. When the shaft is revolved at high speed, the planets are thrown outwards by centrifugal force and their outer surfaces come into contact with the inner surface of a fixed annular casing around which they begin to roll. The disc of each planet is pierced with circular holes and in these fit loosely a corresponding number of rollers and studs carried by discs on the driven shaft. It is through these that the power is transmitted. The gear can be arranged so that if necessary the second shaft is fixed while the casing revolves, while by using planets of a different design the gear can be made reversible. The exhibit attracted considerable attention and it is to be hoped will soon be tried on a large scale.

\section{A Dinosaur from Montana}

During the past summer, a party from the American Museum of Natural History, under the leadership of Mr. Barnum Brown, has explored the Cretaceous rocks of Montana in which remains of fossil reptiles occur. According to a message from the New York correspondent of the Times which appears in the issue of Oct. 1, it has found a nearly complete skeleton of the armadillo-shaped dinosaur Nodosaurus, which has hitherto been known only from fragments. The reptile is remarkably broad, for although it is only $14 \mathrm{ft}$. long, it is $7 \mathrm{ft}$. wide at the hips. It is heavily armoured with bony plates, which are arranged to give flexibility to the trunk and tail. It has feeble teeth adapted for feeding on either vegetables or insects. Nodosaurus was first recognised and named in 1889 by the late Prof. O. C. Marsh, who received characteristic pieces of it from his collectors in the Cretaceous rocks of Wyoming. A somewhat similar fossil skeleton, without head, was discovered in 1913 by the late Mr. W. E. Cutler in corresponding deposits in Alberta, Canada, and it is now exhibited in the British Museum (Natural History). It was named Scolosaurus cutleri by Baron Nopcsa, who published a restored drawing of it by Miss Alice B. Woodward in the Illustrated London News of Sept. 11, 1926. Scolosaurus must have been about $12 \mathrm{ft}$. long, and would be only about $3 \mathrm{ft}$. high when walking. A smaller reptile of the same group was found long ago by the late Rev. William Fox in the Wealden formation in the cliffs on the south coast of the Isle of Wight, but he was able to recover it only in a rather fragmentary state. It was named Polacanthus foxi by Hulke, and is now also exhibited in the British Museum (Natural History).

\section{Memorial to the Late Sir Andrew Balfour}

ON October 6 the Earl of Athlone, Chancellor of the University of London, unveiled a memorial tablet to the late Sir Andrew Balfour, first director of the London School of Hygiene and Tropical Medicine, in the entrance hall of the School. The tablet, which is of polished Roman stone with a bas-relief head in bronze, is the visible part of a twofold memorial, the other purpose being a scheme to enable students, preferably those from overseas, to pursue courses of study at the School. At the ceremony the Chancellor paid a well-deserved tribute to Sir Andrew and his world-wide work in the cause of tropical medicine and public health. Referring to the organisation of the London School of Hygiene and Tropical Medicine he said : "To that work which was, alas, to prove the last of his labours - the building, the equipment, the organisation of this great School-Andrew Balfour brought the same passionate zeal, the same untiring energy which were characteristic of his whole career, and his inspiring personality is so very fresh in the minds of all of you that of his last great piece of work there is hardly any need to speak. The appointment of Andrew Balfour to be the first Director of this School gave to the School from its very inception a splendid introduction throughout the whole world and contributed perhaps more than anything else to the reputation which it has already established. Finally, and in a word, Balfour was a great Empire builder; and when I say this I am thinking not so much of his devotion to work, of his vast knowledge and contributions to the subject of Empire health, not of his academic distinctions, not of his contributions to sport and literature, but of his fine character. He was without guile, honest to the core, a man who evoked in his colleagues a spirit of love and sacrifice." It is fitting that the memorial tablet bears the quotation from Walt Whitman which Balfour himself loved :

"Through the battle, through defeat, moving yet and never stopping,

Pioneers! O pioneers !"

\section{Excavations in Westmeath, Ireland}

ExcEPtional interest is attached to the finds which have been made by the Harvard University Archæological Expedition in excavating a crannog at Ballinderry, near Moate, Co. Westmeath, Ireland, and an early bronze age cairn at Knockast nearby. The excavations are in charge of Dr. H. O'Neill Hencken, whose recent book on Cornwall in the "County Archæologies" series, has given him an assured place among authorities on British archæology. The crannog was first identified by Dr. Adolf Mahr, of the National Museum of Ireland, some four years ago, when a Viking sword was found in the course of cutting a drain across the bog. The island constituting the crannog is built up of layers of brushwood and peat contained by timber piles, on which lay a substructure of massive timbers supporting further layers of peat and brushwood and the floor of a circular dwelling. Above this, and built some time later, were two smaller rectangular houses. Judging from the animal remains, the inhabitants were both hunters and herdsmen, while the coulter of a plough and querns indicate their practice of agriculture. In place of pottery they used well-turned wooden vessels, made on a lathe, and barrels made of staves and hoops. Among the tools and weapons of iron was a Viking battle-axe. The remains are dated at about A.D. 1000. The

No. 3285 , VoL. 130] 